\title{
Terapi Bermain Puzzle pada Anak Usia 3-6 tahun terhadap Kecemasan Pra Operasi
}

\author{
Aprina $^{1}$, Novri Ardiyansa ${ }^{2}$, Sunarsih $^{3}$ \\ Jurusan Keperawatan, Politeknik Kesehatan Tanjung Karang, Indonesia \\ Email: aprinamurhan@yahoo.co.id
}

\begin{abstract}
Playing Puzzle Therapy in Children Aged 3-6 years Preoperative Anxiety. Problems that often appear before surgery are anxiety. Playing is an effective coping method to reduce anxiety experienced by children. This study aims to identify the effect of playing puzzle therapy on preoperative anxiety levels in the Children's Surgery Room of Dr. H. Abdul Moeloek Lampung Province. The design of this study was Quasy Experiment with the design of one group pretest-posttest. This type of quantitative research uses the technique of accidental sampling. The population in this study were 30 preoperative patients. The analysis used is a parametic test of the $t$ test dependent test. When the research began from July 12 to August 12 in the pediatric surgery oroom of Dr. H. Abdul Moeloek Lampung Province. The results show the average anxiety score before therapy is playing puzzle is 64.30 and after giving therapy the role playing puzzle is 48.60 . p-value obtained is 0,000 which indicates the difference in preoperative anxiety scores before and after getting puzzle play therapy in the Children's Surgery Room of Dr. H. Abdul Moeloek Lampung Province.
\end{abstract}

Keywords: Anxiety, Therapy playing puzzle

\begin{abstract}
Abstrak: Terapi Bermain Puzzle pada Anak Usia 3-6 tahun terhadap Kecemasan Pra Operasi. Masalah yang sering muncul sebelum operasi adalah kecemasan. Bermain merupakan cara koping yang efektif untuk mengurangi kecemasan yang dialami oleh anak. Penelitian ini bertujuan mengidentifikasi pengaruh terapi bermain puzzle terhadap tingkat kecemasan pra operasi di Ruang Bedah Anak RSUD Dr. H. Abdul Moeloek Provinsi Lampung. Penelitian ini menggunakan desain quasy experiment dengan rancangan one group pretest-posttest. Jenis penelitian kuantitatif dengan menggunakan teknik accidental sampling. Populasi yang diambil pada peneltian ini yaitu 30 orang yang merupakan pasien yang akan menjalani operasi elektif di Ruang Bedah Anak RSUD Dr. H. Abdul Moeloek Provinsi Lampung. Pengambilan sampel dilakukan dengan teknik accidental sampling. Analisis yang di gunakan adalah uji parametik uji $t$ test dependent. Waktu penelitian mulai 12 juli sampai dengan 12 agustus di ruang bedah anak RSUD Dr. H. Abdul Moeloek Provinsi Lampung. Hasil menunjukkan rata-rata skor kecemasan sebelum dilakukan terapi bermain puzzle adalah 64,30 dan sesudah diberikan terapi bermain peran puzzle adalah 48,60. Didapatkan p-value 0,000 yang menunjukkan adanya perbedaan skor kecemasan pra operasi sebelum dan sesudah mendapatkan terapi bermain puzzle. Terdapat pengaruh terapi bermain puzzle terhadap kecemasan anak pra operasi di Ruang Bedah Anak RSUD Dr. H. Abdul Moeloek Provinsi Lampung.
\end{abstract}

Kata kunci: Kecemasan, Terapi bermain puzzle

\section{PENDAHULUAN}

Pembedahan merupakan suatu tindakan pengobatan yang menggunakan cara invasive dengan membuka dan menampilkan bagian tubuh yang akan ditangani. Pembukaan bagian tubuh dilakukan dengan membuat sayatan. Setelah bagian yang akan ditangani ditampilkan, selanjutnya dilakukan perbaikan yang diakhiri dengan penutupan dan penjahitan luka. Setiap pembedahan selalu berhubungan dengan insisi yang merupakan trauma bagi penderita yang menimbulkan berbagai keluhan dan gejala (Hidayat \& Jong (2005), dalam Aprina, dkk (2017).

Reaksi pasien terhadap pembedahan didasarkan pada banyak faktor, diantaranya ketidaknyamanan dan perubahan-perubahan yang diantisipasi baik fisik, finansial, psikologis, spiritual, sosial atau hasil akhir pembedahan yang diharapkan (Potter, 2006). Prosedur pembedahan akan memberikan suatu reaksi emosional pada pasien, seperti ketakutan atau perasaan tidak tenang, marah, dan kekhawatiran. Persiapan 
mental merupakan hal yang tidak kalah pentingnya dalam proses persiapan operasi karena mental pasien yang tidak siap dapat mempengaruhi kondisi fisiknya. Masalah mental yang biasa muncul pada pasien pra operasi adalah kecemasan (Muttaqin \& Sari, 2009).

Perawatan anak di rumah sakit memaksa anak untuk berpisah dari lingkungan yang dirasakannya aman, penuh kasih sayang dan menyenangkan, yaitu lingkungan rumah, lingkungan permainan dan teman sepermainannya. Anak usia prasekolah tersebut menunjukkan reaksi terhadap perpisahan yaitu dengan menolak makan, sering bertanya, menangis walaupun secara perlahan dan tidak kooperatif terhadap petugas kesehatan. Perawatan anak di rumah sakit juga membuat anak kehilangan kontrol terhadap dirinya. Perawatan di rumah sakit mengharuskan adanya pembatasan aktivitas anak sehingga anak merasa kehilangan kekuatan diri. Kehilangan di rumah sakit sering kali di persepsikan anak prasekolah sebagai hukuman sehingga anak akan merasa malu bersalah, atau takut. Ketakutan anak terhadap perlukaan muncul karena anak menganggap tindakan dan prosedurnya mengancam integritas tubuhnya. Hal ini berakibat munculnya reaksi agresif dengan marah dan berontak, ekspresi verbal dengan mengucapkan kata-kata marah, tidak mau bekerja sama dengan perawat dan ketergantungan pada orang tua.

Anak kecil rentan terhadap kecemasan yang berhubungan dengan perpisahan, sebagai contoh anak yang dirawat di rumah sakit (hospitalisasi) karena anak mengalami urutan ketakutan perkembangan yaitu takut kehilangan ibu, takut kehilangan cinta ibu, takut cidera tubuh, takut akan impulsnya dan takut akan cemas hukuman (punishing unxiety) dari superego dan rasa bersalah. Sebagian besar anak mengalami cemas perpisahan didasarkan pada salah satu atau lebih ketakutan-ketakutan tersebut (Kaplan dan sadock (1997, dalam Nursalam, 2005).

Tingkat kecemasan anak usia pra sekolah yang di rawat inap di rumah sakit masuk dalam kategori tinggi, bahkan ada yang sangat tinggi. Tingkat kecemasan ini harus segera mendapat penanganan agar anak tidak merasa stres berada di rumah sakit. Sebab pikiran yang stres akan menyebabkan anak akan lama pulih dari pengobatan yang sedang dijalani. Oleh karena itu bentuk terapi agar anak merasa nyaman di rumah sakit dapat berupa dengan permainan. Pengukuran skala kecemasan pada anak adalah modifikasi pengukuran kecemasan pada orang dewasa disesuaikan dengan kondisi anak.
Perawat dapat membantu orang tua menghadapi permasalahan yang berkaitan dengan perawatan anaknya di rumah sakit karena perawat berada di samping pasien selama 24 jam. Fokus intervensi keperawatan adalah meminimalkan dukungan psikologis pada anak anggota keluarga. Salah satu intervensi keperawatan yang dapat dilakukan dalam mengatasi dampak hospitalisasi pada anak adalah dengan memberikan terapi bermain. Terapi bermain dapat dilakukan sebelum melakukan prosedur pada anak, hal ini dilakukan untuk mengurangi rasa tegang dan emosi yang dirasakan anak selama prosedur berlangsung.

Walaupun anak mengalami sakit dan atau dirawat, tugas perkembangan tidaklah berhenti. Hal ini bertujuan untuk melanjutkan tumbuh dan kembang selama perawatan sehingga kelangsungan tumbuh kembang dapat berjalan, dapat mengembangkan kreativitas dan pengalaman, anak akan mudah untuk beradaptasi terhadap stres karena penyakit yang di rawat. Prinsip bermain di rumah sakit yaitu tidak banyak mengeluarkan energi, mempertimbangkan keamanan dan infeksi silang, kelompok usia yang sebaya, permainan tidak bertentangan tentang pengobatan, melibatkan orang tua atau keluarga.

Salah satu alternatif untuk mengalihkan perhatian anak yang dirawat di rumah sakit adalah diberikannya dukungan sarana bermain yang dapat memfasilitasi anak untuk mengurangi kecemasan dan ketakutan anak usia prasekolah yang dirawat di rumah sakit, karena anak usia prasekolah masih senang bermain-main.

Bermain merupakan media yang baik untuk belajar, karena dengan bermain anak-anak akan berkata-kata (berkomunikasi), belajar menyesuaikan diri dengan lingkungan, melakukan apa yang dapat dilakukannya dan mengenai waktu jarak serta suara (Wong, 2001 dalam Adriana, 2011).

Data pre survey tanggal 15 Februari 2018 di ruang bedah anak RSUD Dr. H. Abdul Moeloek Provinsi Lampung didapatkan informasi bahwa kejadian operasi pada 4 bulan terakhir yaitu dari bulan Agustus-November 2017 untuk usia 3-6 tahun sebanyak 175 pasien. Di peroleh data $80 \%$ anak mengalami kecemasan. Berdasarkan fenomena tersebut maka peneliti tertarik untuk meneliti pengaruh terapi bermain puzzle terhadap kecemasan pada anak usia 3-6 tahun di RSUD Dr. H. Abdul Moeloek Provinsi Lampung. 


\section{METODE}

Metode yang dilakukan pada penelitian saat ini adalah penelitian Quasy Experiment dengan rancangan one group pretest-posttest Peneliti menggunakan uji $t$ dependent. Populasi dalam penelitian ini adalah anak pra operasi di Ruang Bedah Anak RSUD Dr. H. Abdoel Moeloek Provinsi Lampung. Populasi yang diambil pada peneltian ini yaitu 30 orang yang merupakan pasien yang akan menjalani operasi elektif di Ruang Bedah Anak RSUD Dr. H. Abdul Moeloek Provinsi Lampung. Pengambilan sampel dilakukan dengan teknik accidental sampling. Teknik pengumpulan data menggunakan lembar observasi yang terdiri dari 5 domain dan 22 kategori, menggunakan alat ukur kecemasan MYPAS (Modifiet Yale Preoperatif anxiety scale) Skor 23-100 <30: tidak cemas, 30-53: cemas ringan, 53-77: cemas sedang 78-100: cemas berat.

Penelitian ini telah mendapatkan persetujuan etik penelitian (ecthical clearance) dari Komisi Etik Penelitian Kesehatan Politeknik Kesehatan Tanjung Karang No. 163/EC/KEPTJK/VI/2018.

\section{HASIL}

Tabel 1. Skor Kecemasan Sebelum dan Sesudah diberikan Terapi Bermain Puzzle

\begin{tabular}{lccccc}
\hline Variabel & Mean & Med & SD & $\begin{array}{c}\text { Nilai } \\
\text { Min }\end{array}$ & $\begin{array}{c}\text { Nilai } \\
\text { Maks }\end{array}$ \\
\hline Sebelum & 64,30 & 61,50 & 10,6 & 46 & 31 \\
Sesudah & 48,60 & 46,00 & 11,9 & 83 & 75 \\
\hline
\end{tabular}

Berdasarkan tabel 1 dapat diketahui bahwa rata-rata skor kecemasan kelompok responden sebelum mendapat terapi bermain puzzle adalah 64,30 dengan standar deviasi (SD) 10,697 dan skor kecemasan terendah adalah 46 (cemas ringan) serta skor kecemasan tertinggi adalah 83 (cemas berat) dan rata-rata skor kecemasan kelompok responden sesudah mendapat terapi bermain puzzle adalah 48,60 dengan standar deviasi (SD) 11,970 dan skor kecemasan terendah adalah 31 (cemas ringan) serta skor kecemasan tertinggi adalah 75 (cemas sedang).
Tabel 2. Skor Kecemasan Sebelum Dan Sesudah diberikan Terapi Bermain Puzzle

\begin{tabular}{lccccc}
\hline Kecemasan & Mean & Median & SD & $\begin{array}{c}\boldsymbol{p} \text { - } \\
\text { value }\end{array}$ & $\mathbf{n}$ \\
\hline Sebelum & 64,30 & 61,50 & 10,6 & 0.000 & 30 \\
Sesudah & 48,60 & 46,00 & 11,9 & & \\
\hline
\end{tabular}

Berdasarkan tabel 2 dapat disimpulkan bahwa rata-rata skor indeks kecemasan responden sebelum terapi bermain puzzle adalah 64,30 . Pada pengukuran rata-rata skor kecemasan setelah terapi bermain puzzle didapatkan rata-rata kecemasan adalah 48,60. Nilai perbedaan ratarata skor indeks kecemasan sebelum dan sesudah terapi bermain puzzle adalah 15,7. Hasil uji statistik dengan uji $t$ dependent didapatkan hasil $p$-value sebesar $0,00>a(0,05)$, maka dapat disimpulkan ada pengaruh rata-rata tingkat kecemasan sebelum dan sesudah diberikan terapi bermain puzzle.

\section{PEMBAHASAN}

Hasil penelitian diperoleh data rata-rata skor kecemasan responden sebelum mendapat terapi bermain puzzle adalah 64,30 dengan standar deviasi (SD) 10,697, dan skor kecemasan terendah adalah 46 (cemas ringan) dan skor kecemasan tertinggi adalah 83 (cemas berat). Menurut Stuart, (2007) kecemasan sedang memungkinkan seseorang untuk memusatkan pada masalah yang selektif, namun dapat melakukan sesuatu terarah, kecemasan sedang juga dianggap respon normal terhadap stresor yang dialami individu, secara umum respon cemas dimiliki semua individu, kecemasan merupakan respon yang paling umum yang menyatakan kondisi takut. Anak yang sedang sakit hampir selalu memperlihatkan sikap yang sangat mudah tersinggung, mudah cemas, menjadi pemarah, agresif, penakut, curiga, dan lebih sensitif. Anak dihadapkan pada lingkungan yang asing, orang-orang yang tidak dikenal, dan gangguan terhadap gaya hidup mereka pada saat di rumah sakit.

Sebagian besar stres di usia pertengahan anak periode prasekolah adalah cemas karena perpisahan. Hubungan anak dan ibu sangat dekat, akibatnya perpisahan dengan ibu akan menimbulkan rasa kehilangan pada anak akan orang yang terdekat bagi dirinya dan akan lingkungan yang dikenal olehnya, sehingga pada akhirnya akan menimbulkan perasaan tidak aman dan rasa cemas. 
Menurut Huda (2014) respon kecemasan anak pra sekolah dalam menjalani hospitalisasi sesudah terapi bermain didapatkan sebagian besar responden berada ditahap menolak sebanyak 16 responden $(80 \%)$. Beberapa penyebab kecemasan sebelum pembedahan pada anak usia sekolah muncul terkait dengan membayangkan akan adanya luka pada tubuh setelah dilakukan tindakan pembedahan.

Peran dari petugas kesehatan di rumah sakit (yaitu dokter, perawat), khususnya perawat harus menghargai sikap anak karena selain orang tua, perawat adalah orang yang paling dekat dengan anak selama perawatan di rumah sakit. Meskipun anak menolak perawat, namun perawat harus tetap memberikan dukungan dengan meluangkan waktu secara fisik dekat dengan anak mengajak bermain sesuai tahap perkembangan anak untuk kepentingan terapi.

Anak mempelajari nilai benar dan salah dari lingkungannya, terutama dari orang tua dan guru. Melalui aktivitas bermain, anak akan mendapatkan kesempatan untuk menerapkan nilai-nilai tersebut agar dapat diterima dan dapat menyesuaikan diri dengan aturan-aturan kelompok yang ada dalam lingkungannya. Melalui kegiatan bermain diharapkan anak juga akan belajar nilai moral dan etika, belajar membedakan mana yang benar dan mana yang salah, serta belajar bertanggung-jawab atas segala tindakan yang telah dilakukannya. Misalnya, merebut mainan teman merupakan perbuatan yang tidak baik dan membereskan alat permainan sesudah bermain adalah mengajarkan anak untuk bertanggung-jawab terhadap tindakan serta barang yang dimilikinya. Sesuai dengan kemampuan kognitifnya, bagi anak usia toddler dan prasekolah, permainan adalah media yang efektif untuk mengembangkan nilai moral dibandingkan dengan memberikan nasihat. Oleh karena itu, peran orang tua dianggap penting untuk mengawasi anak saat anak melakukan aktivitas bermain dan mengajarkan nilai moral, seperti baik/buruk atau benar/salah. Pada saat bermain, aktivitas sensoris-motorik merupakan komponen terbesar yang digunakan anak dan bermain aktif untuk perkembangan fungsi otot. Misalnya, alat permainan untuk bayi yang berfungsi mengembangkan kemampuan sensorismotorik dan alat permainan untuk anak usia toddler dan prasekolah yang banyak membantu perkembangan aktivitas motorik baik kasar maupun halus.

Menurut peneliti, kecemasan yang ditunjukkan oleh anak-anak di ruang bedah anak diantaranya adalah anak yang mengalami respon kecemasan ditandai dengan menangis, meminta keluar dari ruang rawat, mencari orang tua dengan pandangan mata dan anak tidak aktif. Berdasarkan respon tersebut peneliti meminimalkan kecemasan dengan melakukan pendekatan dengan cara memberi terapi bermain. Untuk alat permainan yang dirancang dengan baik akan lebih menarik anak dari pada alat permainan yang tidak didesain dengan baik. Alat permainan dengan bentuk sederhana dan tidak rumit dan berwarna terang. Salah satu contoh permainan yang menarik yaitu permainan puzzle, karena puzzle dapat meningkatkan daya pikir anak dan komsentrasi anak. Melalui puzzle anak dapat mempelajari sesuatu yang rumit serta anak akan berpikir bagaimana puzzle dapat tersusun dengan rapi.

Kecemasan pada pasien pra operasi sesudah mendapatkan terapi bermain puzzle ratarata skor kecemasan responden adalah 48,60 dengan standar deviasi (SD) 11,970 dan skor kecemasan terendah adalah 31 (cemas ringan) serta skor kecemasan tertinggi adalah 75 (cemas sedang). Hal ini menunjukkan adanya penurunan kecemasan pada anak sesudah mendapatkan terapi bermain puzzle.

Kecemasan pada anak terhadap keadaan menjadi suatu hal yang dikhawatirkan oleh orang tua sebab kecemasan dapet berdampak pada terganggunya proses tumbuh kembang serta dapat mempengaruhi perilaku anak seperti menjadi susah makan, tidak tenang, takut, gelisah serta berontak saat akan dilakukan tindakan keperawatan sehingga dapat mengganggu dalam proses penyembuhan itu sendiri (Hawari, 2006). Untuk itu menurut (Hawari, 2006) perlu upaya meminimalkan kecemasan dengan cara mencegah atau mengurangi dampak dari kecemasan itu. Salah satu cara untuk meminimalkan kecemasan adalah dengan cara memberi terapi.

Terapi merupakan penerapan sistematis dari sekumpulan prinsip belajar terhadap suatu kondisi atau tingkah laku yang dianggap menyimpang, dengan tujuan melakukan perubahan. Perubahan yang dimaksud bisa berarti menghilangkan, mengurangi, meningkatkan atau memodifikasi suatu kondisi atau tingkah laku tertentu. Secara umum, ada dua jenis terapi. Pertama, terapi jangka pendek untuk masalah ringan, yang dapat diselesaikan dengan memberi dukungan, ide, menghibur, atau membujuk anak. Kedua, terapi jangka panjang untuk masalah yang memerlukan keteraturan dan kontinuitas untuk perubahan perilaku anak (Adriana, 2011).

Bermain adalah suatu konsep yang sangat penting bagi anak. Konsep pembelajaran pada anak adalah bagaimana mereka bermain. Karena 
dengan bermain mereka belajar tentang dunia luar dan lingkunganya dimana mereka berada. Fungsi khusus bermain pada anak mencakup perluasan keterampilan sensorimotor, kreativitas, intelektual dan perkembangan sosial.

Bermain merupakan aspek penting dari kehidupan anak dan salah satu alat paling penting untuk menatalaksanakan stres karena hospitalisasi menimbulkan krisis dalam kehidupan anak, dan karena situasi tersebut sering disertai stres berlebihan, maka anak-anak perlu bermain untuk mengeluarkan rasa takut dan cemas yang mereka alami sebagai alat koping dalam menghadapi stres. Bermain sangat penting bagi mental, emosional, dan kesejahteraan anak seperti kebutuhan perkembangan dan kebutuhan bermain tidak juga ikut terhenti pada saat anak sakit atau anak di rumah sakit.

Supartini (2004) menjelaskan bahwa bermain sebagai aktivitas yang dapat dilakukan anak sebagai stimulasi pertumbuhan dan perkembanganya dan bermain pada anak menjadi media bagi anak untuk mengekspresikan perasaan, relaksasi dan distraksi perasaan yang tidak nyaman selama di rumah sakit. Kegiatan bermain dilakukan secara sukarela untuk memperoleh kesenangan ataupun kepuasan. Dengan melakukan permainan yang menyenangkan dapat membuat anak menjadi senang. Menurut Nursalam et al (2005) dengan bermain akan mempengaruhi kesehatan seorang anak.

Penelitian ini sejalan dengan penelitian Huda (2014) dengan respon kecemasan anak pra sekolah dalam menjalani hospitalisasi sesudah terapi bermain didapatkan sebagian besar responden berada ditahap menolak sebanyak 16 responden $(80 \%)$. Ada pengaruh terapi bermain terhadap respon kecemasan anak prasekolah dalam menjalani hospitalisasi dengan nilai $\rho$ value $=0,000<0,05$ dan Z-skor $-3,874<-1,96$.

Menurut peneliti dapat disimpulkan bahwa terdapat perbedaan skor kecemasan sebelum dan sesudah terapi bermain puzzle. Hal ini dapat disebabkan karena permainan puzzle dapat melatih ketangkasan jari, koordinasi mata dan tangan, mengasah otak, mencocokkan bentuk, konsep kognitif, melatih kesabaran anak dalam menyusun puzzle dan hubungan antar bagian puzzle sehingga menjadi bentuk puzzle yang utuh.

Berdasarkan uji statistik skor kecemasan sebelum dan sesudah diberikan terapi bermain peran puzzle dengan uji $t$ dependen dengan nilai $(<\alpha 0,05)$ didapatkan nilai $p$-value $(0,00)$, maka dapat disimpulkan bahwa ada penggaruh terhadap tingkat kecemasan anak pra operasi sebelum dan sesudah diberikan terapi bermain puzzle.

Kecemasan termasuk kekuatan yang besar dalam menggerakkan tingkah laku. Baik tingkah laku normal maupun tingkah laku yang menyimpang, atau yang terganggu, kedua-duanya merupakan pernyataan, penampilan, penjelmaan dari pertahanan terhadap kecemasan itu (Gunarsa dkk, 2012). Menurut Supartini (2004), adapun reaksi anak usia prasekolah yang menunjukkan kecemasan seperti anak menolak makan, menangis, sering bertanya tentang keadaan dirinya, mengalami sulit tidur, tidak kooperatif terhadap petugas kesehatan saat dilakukan tindakan keperawatan. Tingkat kecemasan pada fase pra operasi anak cukup tinggi sekitar 50$70 \%$ sehingga diperlukan cara untuk mencegah stres emosional anak dapat dilakukan dengan berberapa cara diantaranya persiapan psikologis pada saat preoperatif (sehari sebelum operasi) dimana anak dan orang tua diberikan penjelasan mengenai teknik anastesi dan pembedahan yang akan dijalani keesokan harinya. Perkembangan sosial ditandai dengan kemampuan berinteraksi dengan lingkungannya. Melalui kegiatan bermain, diharapkan anak akan belajar memberi dan menerima. Bermain bersama orang lain membantu anak untuk mengembangkan hubungan sosial dan belajar memecahkan masalah dari hubungan tersebut. Pada saat melakukan aktivitas bermain, anak belajar berinteraksi dengan teman, memahami bahasa lawan bicara, dan belajar tentang nilai sosial yang ada pada kelompoknya. Hal ini terjadi terutama pada anak usia sekolah dan remaja. Meskipun demikian, anak usia toddler dan prasekolah adalah tahapan awal bagi anak untuk meluaskan aktivitas sosialnya dilingkungan keluarga.

Bermain merupakan salah satu cara yang dapat menurunkan kecemasan dengan cara bermain diharapkan kecemasan anak menurun. Anak-anak kecil umumnya berespon lebih baik terhadap permainan dan anak-anak yang lebih besar berespon lebih baik terhadap film sebaya yang dilihatnya (Bates \& Brome, 1986 dalam Wong, 2009).

Terapi bermain adalah usaha mengubah tingkah laku bermasalah, dengan menempatkan anak dalam situasi bermain. Bermain merupakan cerminan kemampuan fisik, intelektual, emosional dan sosial. Bermain merupakan media yang baik untuk belajar karena dengan bermain anak-anak akan berkata-kata (berkomunikasi), belajar menyesuaikan diri dengan lingkungan, melakukan apa yang dapat dilakukannya dan mengenai waktu jarak serta suara (Wong, 2001 dalam Adriana, 2011). 
Terapi bermain diharapkan mampu menghilangkan batasan, hambatan dalam diri, stres, frustasi serta mempunyai masalah emosi dengan tujuan mengubah tingkah laku anak yang tidak sesuai menjadi tingkah laku yang diharapkan dan anak yang sering diajak bermain akan lebih kooperatif dan mudah diajak kerjasama selama masa perawatan (Mulyaman 2006 dalam Yusuf dkk, 2013). Bermain juga menjadi media terapi yang baik bagi anak-anak untuk dapat mengembangkan potensi kreativitas dari anak-anak itu sendiri. Untuk mengurangi kecemasan pada anak yang menjalani hospitalisasi dapat dilakukan diantaranya dengan relaksasi, terapi musik, aktivitas fisik, terapi seni dan terapi bermain.

Sejalan dengan pertumbuhan dan perkembangannya, anak usia prasekolah mempunyai kemampuan motorik kasar dan halus yang lebih matang dari pada anak usia toddler. Anak juga sudah lebih aktif, kreatif dan imajinatif. Demikian juga kemampuan berbicara dan berhubungan sosial dengan temannya semakin meningkat. Untuk itu, jenis alat permainan yang tepat diberikan pada anak misalnya, bermain puzzle, membacakan cerita/dongeng, alat gambar dan permainan balok-balok besar.

Pemilihan permainan puzzle di dalam terapi permainan ini karena puzzle merupakan salah satu permainan edukatif yang dapat mengoptimalkan kemampuan dan kecerdasan anak. Bermain puzzle mengajarkan anak untuk bersabar dan melatih keterampilan anak dalam menyusun puzzle untuk kembali menjadi puzzle yang utuh. Menurut Soebachman (2012) bermain puzzle merupakan permainan yang terdiri atas kepingan-kepingan dari satu gambar tertentu yang dapat melatih tingkat konsentrasi. Bermain puzzle dapat dilakukan oleh anak-anak hingga anak belasan tahun, tetapi tentu saja tingkat

\section{DAFTAR PUSTAKA}

Adriana, D. (2011). Tumbuh Kembang \& Terapi Bermain Pada Anak. Jakarta: Salemba Medika.

Aprina, A., Yowanda, N. I., \& Sunarsih, S. (2017). Relaksasi Progresif terhadap Intensitas Nyeri Post Operasi BPH (Benigna Prostat Hyperplasia). Jurnal Kesehatan, 8(2), 289-295.

Gunarsa, S. (2012). Dasar teori perkembangan anak. Jakarta: PT. BPK Gunung Mulia.

Hawari, D. (2006). Manajemen Stress, Cemas, Depresi. Jakarta: FKUI. kesulitannya harus di sesuaikan anak yang memainkanya. Bermain puzzle anak akan mencoba memecahkan masalah yaitu menyusun gambar (Vernanda, Yunus, \& Rahmahtrisilvia, 2013).

Penelitan ini sejalan dengan hasil penelitian yang dilakukan Kaluas (2015) menunjukkan terapi bermain puzzle memiliki pengaruh yang signifikan untuk menurunkan respon kecemasan anak prasekolah selama hospitalisasi dimana didapat nilai mean sesudah pemberian terapi bermain puzzle yaitu 28,71. Terapi bermain dengan puzzle sangat bermakna dalam mengurangi kecemasan pada anak karena membutuhkan kesabaran dan ketekunan anak dalam merangkainya, lambat laun akan membuat mental anak terbiasa untuk bersikap tenang, tekun dan sabar dalam menghadapi dan menyelesaikan sesuatu.

Menurut peneliti, jika melihat dari analisis univariat dan bivariat skor kecemasan sebelum dilakukan terapi bermain puzzle adalah 64,30 dan sesudah diberikan terapi bermain peran puzzle adalah 48,60. Dan setelah di uji $t$ dependent didapatkan nilai $p$-value $0,00(<\alpha 0,05)$.

\section{SIMPULAN}

Terdapat pengaruh terapi bermain puzzle terhadap kecemasan anak pra operasi. Hal tersebut dikarenakan terapi bermain puzzle dapat mengalihkan perhatian anak sehingga pikiran anak tidak terlalu fokus terhadap tindakan pembedahan yang akan dilakukan. Selain itu penerapan terapi bermain menunjukan prilaku saling mengerti antara perawat dengan anak, sehingga akan menumbuhkan saling percaya.

Huda, M., \& Hadi, N. (2014). Pengaruh terapi bermain terhadap respon kecemasan anak usia prasekolah dalam menjalani hospitalisasi di ruang seruni rumah sakit umum daerah jombang. Jurnal Metabolisme, 3(1), 1-5.

Kaluas, I., Ismanto, A. Y., \& Kundre, R. M. (2015). Perbedaan Terapi Bermain Puzzle Dan Bercerita Terhadap Kecemasan Anak Usia Prasekolah (3-5 Tahun) Selama Hospitalisasi Di Ruang Anak RS TK. III. 
Rw Mongisidi Manado. Jurnal Keperawatan, 3(2).

Muttaqin, A., \& Sari, K. (2009). Asuhan keperawatan perioperatif konsep, proses, dan aplikasi. Jakarta: Salemba Medika.

Nursalam, R. S., \& Utami, S. (2005). Asuhan Keperawatan Bayi dan Anak (untuk perawat dan bidan). Jakarta: Salemba Medika.

Nursalam, \& dkk. (2013). Asuhan Keperawatan Bayi dan Anak Edisi 2. Jakarta: Salemba Medika

Potter, P. A \& Perry, A. G. (2006). Buku Ajar Fundamental Keperawatan: konsep, proses dan praktik, Edisi ke-4. Jakarta: EGC.

Soebachman, A. (2012). Permainan Asyik Bikin Anak Pintar. Yogyakarta: IN AzNa Books.

Stuart, G. (2007). Buku Saku Keperawatan Jiwa, Ed.5 (Ramona \& Egi, Penerjemah). Jakarta: EGC.
Supartini, Y. (2004). Konsep Dasar Keperawatan Anak. Jakarta: EGC.

Vernanda, G., Markis Yunus, Rahmahtrisilvia. (2013). Meningkatkan kemampuan mengenal huruf vocal melaui media puzzle bagi anak kesulitan belajar kelas ii di sdn 18 koto luar. JURNAL ILMIAH PENDIDIKAN KHUSUS, Vol 2 No 3. http://ejournal.unp.ac.id/index.php/jupekhu

Wong, D.L., Eaton, M.H., Wilson, M.L., Schwartz, P. (2009). Buku ajar keperawatan pediatrik. Vol 2. Jakarta: EGC.

Yusuf. M, dkk. (2013). Pengaruh terapi bermain terhadap kondisi psikologis anak usia pra sekolah yang mengalami hospitalisasi di rumah sakit umum daerah dr. Zainoel abidin banda aceh the impact of play therapy on hospitalized children psychological condition at seurune ward. Jurnal Kesehatan Ilmiah Nasuwakes Vol, 6(2), 149-157. 